\title{
A national multidisciplinary healthcare network for treatment of hepatitis $C$ in people who inject drugs in Slovenia
}

Mojca Maticic

Slovenia's estimated $1 \%-2.5 \%$ hepatitis $\mathrm{C}$ virus (HCV) seroprevalence rate in the general population is much lower than the $3.5 \%$ rate reported by neighbouring Italy [1]. There are an estimated 10,000 people who inject drugs (PWID) in Slovenia, a country of two million. HCV seroprevalence in PWID in Slovenia has been estimated at $23 \%$ - the second-lowest rate in the European region and HIV co-infection is extremely rare $[2,3]$. Around 4,500 PWID per year receive services at regional Centers for the Prevention and Treatment of Drug Addiction (CPTDA), with around three-quarters receiving opioid substitution treatment [4]. In 2006, HCV RNA prevalence among 1,450 PWID managed at CPTDA was $15.6 \%$; $1 \%$ of the infected cohort had completed HCV treatment and 3\% were currently receiving it [5].

In Slovenia, the relatively low HCV seroprevalence in PWID most probably reflects the systematic introduction of various well-established harm reduction interventions in the early 1990s [4]. At the beginning of the last decade, however, the HCV treatment rate for PWID was reported to be very low, as was the case in other European countries [6]. To increase the HCV treatment rate, a national model for the management of $\mathrm{HCV}$ infection in this vulnerable population was introduced.

$\mathrm{HCV}$ is managed by two institutions in Slovenia: the National Institute of Public Health of the Republic of Slovenia and the National Viral Hepatitis Expert Group, the latter a multidisciplinary body of experts from various public medical institutions. The National Institute of Public Health is responsible for national epidemiological surveillance and for HCV prevention strategies such as blood safety, vaccination and contact tracing. The National Viral Hepatitis Expert Group, which was founded by a self-initiative in 1997, guides the overall national strategy for the management of viral hepatitis, drawing on best

Correspondence: mojca.maticic@kclj.si

Clinic for Infectious Diseases and Febrile Illnesses, University Medical Centre, Ljubljana, Slovenia practices and standards of care as much as possible. Case finding in special groups, anonymous testing, treatment, national consensus guidelines, research, education and mass media campaigns are all issues that fall within the Expert Group's domain [7].

Slovenia formulated national guidelines for treatment of HCV infection in 1997, basing the guidelines on international recommendations while taking into account national particularities [7]. Treatment in Slovenia is fully publicly funded and is provided with no limitations except for one: it must be prescribed by viral hepatitis specialists at one of five hospital-based clinics in accordance with national guidelines. The 1997 guidelines did not exclude PWID from HCV treatment, stating that treatment decisions should be made on an individual basis. Since 1997, the Expert Group has systematically monitored treatment efficacy and safety in Slovenian patients treated for hepatitis C.

In 1995, 18 CPTDA were established in Slovenia. When a PWID enters a CPTDA programme, the person is offered $\mathrm{HCV}$ testing. Individuals who test negative are invited to be tested again every six to 12 months [4]. To increase the proportion of PWID treated for HCV and to achieve optimal treatment adherence, efficacy and safety, a multidisciplinary national healthcare network for the treatment of HCV infection in PWID was established in 2007 [8]. This network linked the 18 CPTDA and the five specialised hosptial-based clinics for treatment of viral hepatitis. The Clinic for Infectious Diseases and Febrile Illnesses at the University Medical Centre in Ljubljana serves as the reference institution.

The network for the treatment of HCV in PWID includes clinical care providers (addiction therapists and viral hepatitis specialists, most of whom are infectologists), counsellors (nurses and social workers), and psychiatrists who have acquired additional medical education and supportive training. It also includes peers and other members of patient support systems such as family members, 
friends and co-workers. Collaboration among all involved health professionals takes place through participation in national conferences that have been held annually since 2006.

Slovenian national consensus guidelines for the management of HCV infection in drug users were established in 2007 [8]. These guidelines set forth best practices for the comprehensive management of $\mathrm{HCV}$-infected PWID. They provide best practices for screening and identifying treatment-eligible PWID, as well as for providing them with high-quality HCV education, counselling and motivation. Best practices for treatment of $\mathrm{HCV}$ in clinical settings for viral hepatitis are provided, with at least monthly interventions performed individually throughout the treatment period in close cooperation between viral hepatitis specialists and addiction therapists.

Before the introduction of the multidisciplinary model, PWID made up the following proportions of all patients treated for HCV in Slovenia: $5 \%$ in 1997-1999, $16 \%$ in 1999-2001 and 36\% in 2002-2004 [9-11]. In 2008-2010, this proportion increased to $78 \%$. It is notable that by the end of 2010 approximately $13 \%$ of HCV-infected PWID at CPTDA had already received treatment. The sustained virological response among PWID was $80 \%$ in the last monitoring period [11].

In conclusion, the multidisciplinary healthcare network enables individual evaluation and management of HCV-infected PWID by both drug addiction therapists and viral hepatitis specialists in a convenient, experienced and effective manner in the context of Slovenian circumstances. Since healthcare systems and settings vary greatly across Europe, each European country should try to develop its own interdisciplinary model for addressing the treatment of HCV in PWID.

\section{Competing interests}

The authors declare that they have no competing interests.

\section{Declarations}

This article has been published as part of BMC Infectious Diseases Volume 14 Supplement 6, 2014: Viral Hepatitis in Europe. The full contents of the supplement are available online at http://www.biomedcentral.com/ bmcinfectdis/supplements/14/S6. The publication charges for this supplement were funded by AbbVie as an unrestricted grant to Rigshospitalet, the University of Copenhagen. AbbVie further funded the printing of the supplement with additional financial support from the Drug Prevention and Information Programme (DPIP) of the European Union.

\section{Published: 19 September 2014}

\section{References}

1. Esteban JI, Sauleda S, Quer J: The changing epidemiology of hepatitis C virus infection in Europe. J Hepatol 2008, 48:148-162.

2. European Centre for Disease Prevention and Control Technical Report: Surveillance and prevention of hepatitis B and C in Europe. Stockholm: ECDC; 2010, Available from: http://ecdc.europa.eu/en/publications/ Publications/101012TERHepBandCsurvey.pdf.

3. Seme K, Lunar MM, Tomažič J, Vidmar L, Karner P, Matičič M, Poljak M: Low prevalence of hepatitis $B$ and hepatitis $C$ virus infections among HIV infected individuals in Slovenia: A nationwide study 1986-2008. ActaDermatoven APA 2009, 18:153-6.

4. Kastelic A, Kostnapfel T: Opioid substitution treatment programs in Slovenia. Zdrav Vestn 2010, 79:575-81.

5. Matičič $M$ : Management of hepatitis $C$ virus infection in drug users: Slovenian experiences and national guidelines. 1st World Conference on Medication Assisted Treatment of Opiate Addiction. 2007 Jul 2-4. Ljubljana, Slovenia. EUROPAD, AATOD, SEEA net 2007, 29-30.

6. Reimer J, Schulte B, Castells X, Schafer I, Polywka S, Hedrich D, Wiessing L, Haasen C, Backmund M, Krausz M: Guidelines for the treatment of hepatitis $C$ virus infection in injection drug users: status quo in the European Union countries. Clin Infect Dis 2005, 40(Suppl 5):S373-8.

7. Maticic M, Brinovec V, Lesnicar G, Vidmar L, Meglic-Volkar J: Hepatitis C v Sloveniji. ISIS 1999, 8:49-51.

8. Maticic M, Kastelic A: National guidelines for the management of hepatitis C virus infection in drug users in Slovenia. Zdrav Vestn 2009, 78:529-539.

9. Brinovec V, Lešničar G, Maticic M, Meglič-Volkar J, Poljak M, Seme K, FerlanMarolt V: Efficacy of chronic hepatitis C therapy with interferon alpha (IFN-alpha) in Slovenia. Hepato-Gastroenterol 2002, 49:1320-5.

10. Brinovec V, Lešničar $G$, Meglic-Volkar J, Maticic M, Baklan Z, Poljak M, Seme K, Ferlan-Marolt V, Luzar B: Treatment of chronic hepatitis C: our experience. Hepato-Gastroenterol 2004, 51:494-9.

11. Maticic M, Selic-Kurincic T, Kastelic A, Poljak M, Lesnicar G, Meglic-Volkar J, Rajter M, Prah J, Kotar T, Cuk J, Kodre-Rebolj AM: A national multidisciplinary healthcare network for treatment of hepatitis $C$ in people who inject drugs in Slovenia: high enrollement, adherence and sustained virological response. Suchtmed 2013, 15:245.

doi:10.1186/1471-2334-14-S6-S6

Cite this article as: Maticic: A national multidisciplinary healthcare network for treatment of hepatitis $C$ in people who inject drugs in Slovenia. BMC Infectious Diseases 2014 14(Suppl 6):S6.

\section{Submit your next manuscript to BioMed Central and take full advantage of:}

- Convenient online submission

- Thorough peer review

- No space constraints or color figure charges

- Immediate publication on acceptance

- Inclusion in PubMed, CAS, Scopus and Google Scholar

- Research which is freely available for redistribution 